\title{
The use of the Big Book to Improve Scientific Literacy Skill in 5th Grade Elementary Schools Students
}

\author{
Baharudin Akhmad ${ }^{1}$, Tukiran Taniredja ${ }^{2}$, Sudibdya Santosa $^{3}$, Anton Herman Suyitno ${ }^{4}$ \\ $\left\{\right.$ baharudin.fortuner@gmail.com ${ }^{1}, \underline{\text { tukiranump@gmail.com }}{ }^{2}$, masdieb @gmail.com $^{3}$, \\ antonherman94@gmail.com ${ }^{4}$ \} \\ 1,2,3,4 Magister Pendidikan Dasar, Universitas Muhammadiyah Purwokerto \\ Jl KH Ahmad Dahlan, Banyumas 53182, Indonesia
}

\begin{abstract}
Teachers have not used literacy-rich media to stimulate students' reading interests and improve their scientific literacy skills, due to the low literacy. The objective of this research was to investigate the benefits of big book media as a method for improving scientific literacy skills in 5th grade elementary school students. This study employs a Systematic Literature Review as its methodology. Secondary data is the type of data used. Data was gathered by documenting and analyzing 18 articles based on research topics published between 2013 and 2021 and found via Google Scholar searches. According to the findings of the study, indicated that the use of big books can help improve science literacy skills significantly for 5th grade elementary school students it shows that the use of big books can help improve science literacy skills significantly for 5 th grade elementary school students.
\end{abstract}

Keywords: big book, scientific literacy skill, elementary school

\section{Introduction}

Literacy skills are needed by students to deal with various existing information so that they can sort and choose according to facts and reality. The government has encouraged all schools to mobilize a national literacy movement. For those who focus on dealing with education issues, they are certainly familiar with the national literacy movement.

Scientific literacy is a person's ability to solve scientific problems related to the natural environment so that it is beneficial for him both at school and in everyday life [1]. There are two main components in scientific literacy, namely First, lifelong learning competencies, including equipping students to study in further schools. Second, competence in using the knowledge it has to meet the needs of life which is heavily influenced by the development of science and technology [2].

According to the National Science Teacher Association (NSTA), people who master scientific literacy can use scientific knowledge to solve problems related to the natural environment so that it is very beneficial for themselves both at school, society, nation, and the world which is ultimately implemented in all aspects of life[3]. Then, according to PISA research, Indonesia's scientific literacy ability is ranked 70 out of 78 countries that are members of PISA with a score of 396 [4]. The development of scientific literacy is important so that students have scientific knowledge, scientific process skills, and scientific attitudes [5]. The results of the 2011 TIMSS study, Indonesia 
was ranked 40th followed by 42 countries, showing an average science achievement score of 406 , which is a decrease from 2007 [6].

The reality on the ground, the scientific literacy ability of grade 5 students at SD Negeri 2 Grecol for the 2020/2021 academic year is still low. This can be seen from the low initial test results on the knowledge aspect showing a score of 2.40. Based on the results of interviews with school principals, teachers have not used media that contains literacy that attracts reading interest and increases students' scientific literacy skills. The results of the questionnaire showed that 17 out of 25 students were more interested in reading science books with interesting pictures. Students feel bored if they read books that are not given pictures. To improve scientific literacy skills, it is first necessary to increase reading interest, especially related to finding science content in elementary schools in an interesting media.

The use of media in the learning process must be in accordance with the material to be delivered and contain messages that serve to increase student interest in learning and are also expected to achieve learning objectives [7]. Learning media must also be adapted to the characteristics of students, the type of material, the situation and environmental conditions, as well as the location where the learning process takes place [8]. The function of the media in learning activities is not just a teacher's tool, but a carrier of information or messages according to the needs of students [9].

There are so many media that can be used to help improve scientific literacy skills, one of which is Big Book [10]. The use of Big Books can be used as an effort to improve scientific literacy skills because this media has many pictures, and large writing [11].

There are various sizes of Big Book media, including sizes A3, A4, A5, or the size of newsprint [38]. A good Big Book has the characteristics of a story that is used there are only 10-15 pages [12]. Big books have large sizes and writings and are in the form of colorful series images that help students understand the content of the story or even stimulate students' imaginations [13]. The big book media has advantages, including: (1) large text and images so that all students in the class see it, (2) the material is made concise and clear, and (3) has a striking color that attracts students' attention [14].

The results showed that the enthusiasm of students in receiving learning materials using big book media was very high, so that students understood the material presented by the teacher more quickly [15]. Because using the right media can explain and describe learning materials concretely and can help understand learning materials [3].

\section{Methods}

This study uses the Systematic Literature Review (SLR) method. Research begins by looking for articles related to the research topic to be carried out. In research, there are five stages that must be carried out in the Systematic Literature Review method, namely: formulating research questions, searching for articles, evaluating articles, summarizing articles, interpreting article findings [15]. This Systematic Literature Review (SLR) is carried out by identifying, reviewing, evaluating, and interpreting all existing research. With this method, researchers review and identify journals in a structured manner, which in each process follows predetermined steps [16]. Researchers collect journal articles on the Google Scholar database. The keywords used in the article search were Big Book, Science Literacy Ability, Elementary School Students. The articles collected are only articles published in the period 2013 to 2021 with the aim of obtaining information that is still fresh and follows the development of knowledge. 
From these articles, the researcher selected 18 articles from accredited national and international journals that were closely related to the keywords used. The next step, researchers classify articles related to Big Book, Science Literacy Ability, Elementary School Students in general. Article metadata is tabulated in a table containing the author's name, year of publication, journal name, type of research, and research results. After that, the researcher reviewed and analyzed the article in depth, especially regarding the research results presented in the discussion and conclusion section. At the end of the study, the researcher conducted a review and identified the journals in a structured manner which in each process followed the steps that had been set [16]. At the end of the study, the researcher compares the findings presented in the article and draws a conclusion [16].

\section{Results and Discussion}

The use of big books in science learning can be an alternative to improve students' reading skills so as to motivate students to have high cultural reading power [17]. The use of big book media in learning is useful for generating information, providing an experience, guiding students in understanding the contents of the book, introducing various types of reading so that students are actively involved in learning [18]. A quality big book helps students understand basic knowledge so that it will encourage students to like to read the knowledge information contained in it [19].

The following are the results of research on the use of Big Books in learning to improve scientific literacy skills in elementary schools as presented in table 1 below:

Table 1. Literature Search Synthesis Analysis

\begin{tabular}{|c|c|c|c|}
\hline Researcher Name & Year & Journal & Research result \\
\hline $\begin{array}{l}\text { Mi-Hyun Chung \& } \\
\text { Barbara Keckler, } \\
\text { Mercy College }\end{array}$ & 2016 & $\begin{array}{l}\text { Language and } \\
\text { Literacy Spectrum } \\
\text { Volume } 26\end{array}$ & $\begin{array}{l}\text { Books that children read to strengthen } \\
\text { scientific concepts and processes. Teachers } \\
\text { can encourage students to explore scientific } \\
\text { vocabulary, concepts, and process skills } \\
\text { from an early age with quality books }\end{array}$ \\
\hline $\begin{array}{l}\text { Tara Concannon dan } \\
\text { Gibney }\end{array}$ & 2013 & $\begin{array}{l}\text { Proceedings of the } \\
2013 \text { Annual } \\
\text { Conference of The } \\
\text { Reading Association } \\
\text { of Ireland }\end{array}$ & $\begin{array}{l}\text { Books that children read to strengthen } \\
\text { scientific concepts and processes. Teachers } \\
\text { can encourage students to explore scientific } \\
\text { vocabulary, concepts, and process skills } \\
\text { from an early age with quality books }\end{array}$ \\
\hline $\begin{array}{l}\text { Riska Dwi } \\
\text { Puspaningrum and } \\
\text { Ganes Gunansyah }\end{array}$ & 2015 & $\begin{array}{l}\text { Primary school } \\
\text { teacher education } \\
\text { journal }\end{array}$ & $\begin{array}{l}\text { The results showed that the use of big book } \\
\text { media was proven to be effective in } \\
\text { increasing information literacy skills } \\
\text { during learning. }\end{array}$ \\
\hline $\begin{array}{l}\text { Niky Kumala Putri } \\
\text { and Mintohari }\end{array}$ & 2017 & $\begin{array}{l}\text { Primary school } \\
\text { teacher education } \\
\text { journal }\end{array}$ & $\begin{array}{l}\text { The results showed that using the big book } \\
\text { media was proven to be effective in } \\
\text { improving students' cognitive learning } \\
\text { outcomes. Big book media can also attract } \\
\text { students attention and interest in learning. }\end{array}$ \\
\hline $\begin{array}{l}\text { Hengki Dwi Julianto } \\
\text { and Farida Istianah }\end{array}$ & 2017 & $\begin{array}{l}\text { Primary school } \\
\text { teacher education } \\
\text { journal }\end{array}$ & $\begin{array}{l}\text { The results of the study concluded that a } \\
\text { positive response to the use of big book } \\
\text { media in natural resource material learning } \\
\text { showed that the students' response was very }\end{array}$ \\
\hline
\end{tabular}




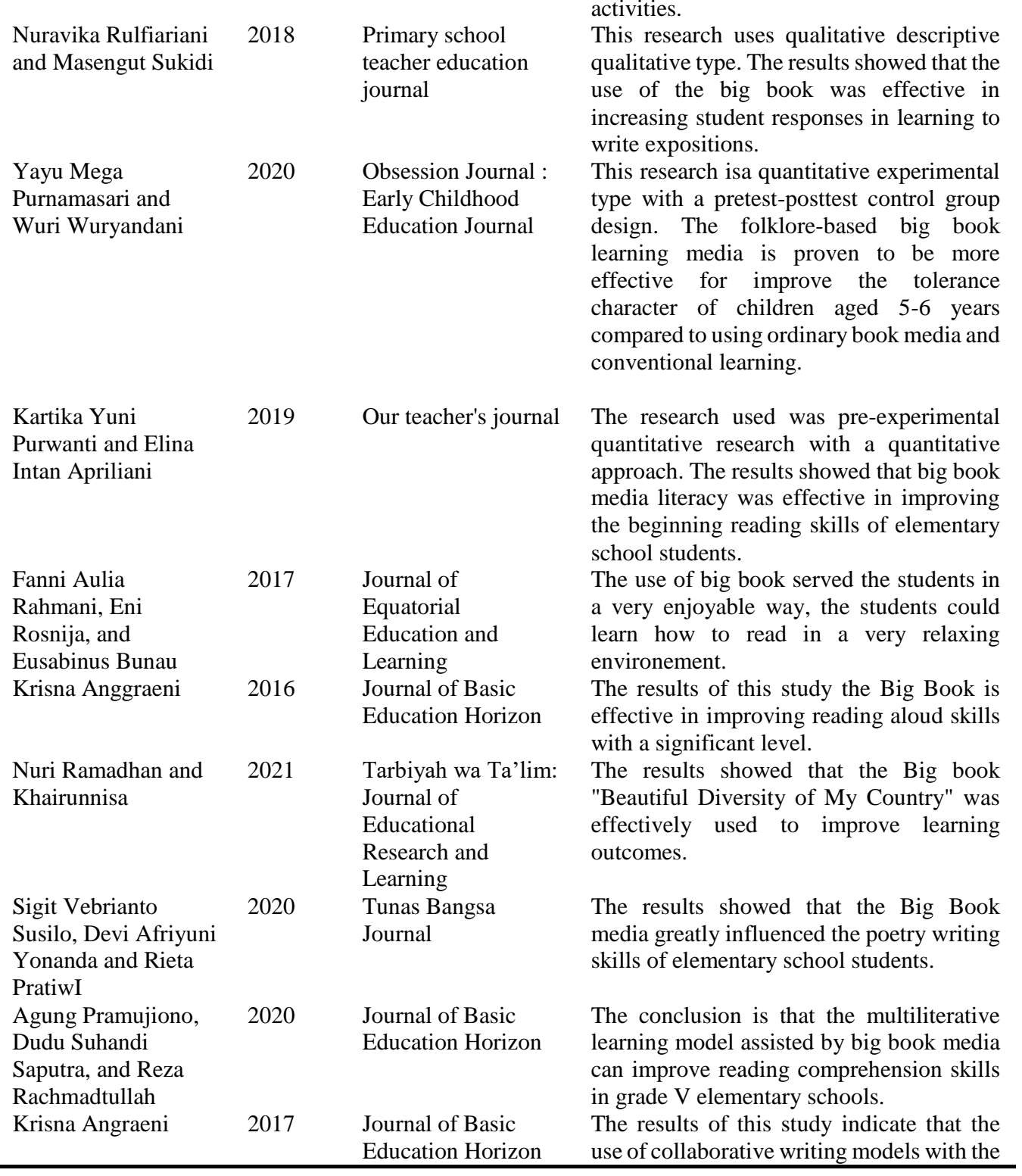




\begin{tabular}{|c|c|c|c|}
\hline & & & $\begin{array}{l}\text { Big Book supports creative writing } \\
\text { learning. }\end{array}$ \\
\hline $\begin{array}{l}\text { Agung Cahya } \\
\text { Karyadi }\end{array}$ & 2018 & $\begin{array}{l}\text { Community Service } \\
\text { Journal } \\
\text { Teacher Training } \\
\text { and Education }\end{array}$ & $\begin{array}{l}\text { The results showed that the storytelling } \\
\text { method using big book media can improve } \\
\text { children's speaking skills. }\end{array}$ \\
\hline $\begin{array}{l}\text { Gunanti } \\
\text { Setiyaningsih and } \\
\text { Amir Syamsudin }\end{array}$ & 2019 & $\begin{array}{l}\text { Scholaria: Journal of } \\
\text { Education and } \\
\text { Culture. }\end{array}$ & $\begin{array}{l}\text { The big book media developed has Aiken's } \\
\text { validity which is quite valid. The media big } \\
\text { book developed can be used every day for } \\
\text { literacy learning. }\end{array}$ \\
\hline $\begin{array}{l}\text { Arina Restian and } \\
\text { Suhesti Maslikah }\end{array}$ & 2019 & $\begin{array}{l}\text { Journal of Basic } \\
\text { Education Horizon }\end{array}$ & $\begin{array}{l}\text { The results showed that the development of } \\
\text { big book media was able to make students } \\
\text { enthusiastic and feel happy in learning. }\end{array}$ \\
\hline $\begin{array}{l}\text { Azimi, Ani } \\
\text { Rusilowati, and } \\
\text { Sulhadi }\end{array}$ & 2017 & $\begin{array}{l}\text { Pancasakti Science } \\
\text { Education Journal }\end{array}$ & $\begin{array}{l}\text { The results of the study were that the Big } \\
\text { Book Media based on scientific literacy } \\
\text { was stated to be effective in its use in } \\
\text { learning. Effectiveness is seen based on the } \\
\text { results of reports on practicum activities, } \\
\text { learning outcomes, scientific literacy } \\
\text { abilities. }\end{array}$ \\
\hline
\end{tabular}

Based on the results of research that has been carried out as shown in Table 1, the use of big books to improve scientific literacy skills in learning in elementary schools has an impact on strengthening scientific processes and concepts and is effective in improving students' scientific literacy skills [6][20]. In addition to mastering scientific processes and concepts, with the use of big books students become enthusiastic and happy in learning [6][11][21-22][23]. The use of big books can improve information literacy skills, expository writing, tolerance character, aloud reading skills, preliminary reading skills, and poetry writing skills [7][24-28]. If the big book is combined with a learning model, it can improve literacy skills in students such as reading comprehension skills, creative writing, so that scientific literacy concepts and knowledge can be developed [29][23][28][31][32].

\section{Conclusion}

After analyzing various journals selected by the literature study method, it can be concluded that big books can improve scientific literacy skills through activities of planting scientific concepts through the reading process. This is because big books are able to attract and increase students' interest in scientific literacy. Other skills will emerge such as information literacy skills, exposition writing, tolerance character, aloud reading skills, beginning reading skills, and poetry writing skills after using big books in learning.

Big book as a learning media has a significant effect in improving literacy skills, one of which is scientific literacy. Agree with Rudi and Cepi (2009:9) states that the function of media in learning activities is not just a teacher's tool, but a carrier of information or messages according to the needs of students. 


\section{References}

[1] Hana dan Ridwan Iskandar. (2020). Literasi Sains Siswa Melalui Penerapan Model Pembelajaran Blended Learning dengan Blog. Naturalistic: Jurnal Kajian Penelitan dan Pendidikan dan Pembelajaran Vol.4, No.2b (April 2020): 597-604

[2] Kharizmi, Muhammad. (2015). Kesulitan Siswa Sekolah Dasar dalam Meningkatkan Kemampuan Literasi. JUPENDAS, ISSN 2355-3650, Vol. 2, No. 2: 11-21

[3] Oktavia, J. (2016). Big book dalam Pembelajaran Reading Comprehension untuk Mengembangkan Critical Reading Siswa Kelas V Sekolah Dasar. Jurnal Antologi UPI, 1-9.

[4] OECD (2019), PISA 2018 Results (Volume I): What Students Know and Can Do, PISA, OECD Publishing, Paris, https://doi.org/10.1787/5f07c754-en.

[5] Fakhriyah, et.al. (2017). Student's Science Literacy In The Aspect Of Content Science. Jurnal Pendidikan IPA Indonesia: 6 (1) (2017) 81-87. DOI: 10.15294/jpii.v6i1.7245.

[6] Concannon, Tara\&Gibney. 2013. Using a Big Book to Teach Essential Literacy Skills. Language, Literacy and Literature: Re-imagining Teaching and Learning. Proceedings of the 2013 Annual Conference of The Reading Association of Ireland, pp. 24-34.

[7] Rulfiariani, Nuravika dan Masengut Sukidi. (2018). Efektivitas Penggunaan Media Big Book dalam Pembelajaran Menulis Eksposisi Siswa Kelas III SDN Wiyung I/453 Surabaya. JPGSD. Volume 06 Nomor 04 Tahun 2018, 629-639

[8] Sadiman, Arief. 2014. Media Pendidikan. Jakarta: PT Raja Grafindo Persada

[9] Susilana, Rudi dan Cepi Riyana. (2009). Media Pembelajaran: Hakikat Pengembangan, Pemanfaatan, dan Penilaian. Bandung: CV Wacana Prima

[10] Harimurti. (2010). Upaya Meningkatkan Kemampuan Pra-Membaca Anak Usia 4-5 Tahun melalui Metode Pendekatan Big book di Taman Kanak-kanak

[11] Julianto, Hengki Dwi dan Farida Istianah. (2017). Pengaruh Media Big Book Terhadap Hasil Belajar Pada Meteri Sumber Daya Alam Kelas IV Sekolah Dasar Babatan 1/456 Surabaya. JPGSD Volume 05 Nomor 03, 348-357

[12] USAID. 2014. Buku Sumber untuk Dosen LPTK: Pembelajaran Literasi Kelas Awal SD/MI di LPTK. Jakarta: USAID

[13] Hawania, Hesti Pungki dan Julianto. (2020). Pengembangan Media Big Book Pada Pembelajaran IPA Materi Siklus Hidup Hewan Kelas IV Sekolah Dasar. JPGSD. Volume 08 Nomor 02, 302 - 315

[14] Susan \& Barbara. 2006. Using Big Book: A Sta ndardsBased Instructional Approach for Foreign Language Teacher Candidates in a PreK-12 Program. University of Akron (Vol. 39, No. 3), 1-20

[15] [15] Khan, K. S., Kunz, R., Kleijnen, J., \& Antes, G. (2003). Five steps to conducting a systematic review. Journal of the Royal Society of Medicine, 96(3), 118-121. https://doi.org/10.1177/014107680309600304

[16] Triandini, E., Jayanatha, S., Indrawan, A., Putra, G. W., \& Iswara, B. (2019). Metode Systematic Literature Review untuk Identifikasi Platform dan MetodePengembanganSistemInformasi di Indonesia. IJIS: Indonesian Journal of Information Systems, 1(2), 63-77. https://doi.org/10.24002/ijis.v1i2.1916 Nursalim, Mochamad, dkk. (2016). Psikologi Pendidikan. Surabaya: Unesa University Press 
[17] Dewi, Ria Susiswati Anita. 2016. Efektivitas Penggunaan Media Big Book Dalam Pembelajaran Menyimak Siswa Kelas V Sd Hang Tuah 3 Surabaya: Universitas Negeri Surabaya.

[18] Solehuddin, M, dkk. (2012). Pembaharuan Pendidikan TK. Tangerang Selatan: Universitas Terbuka.

[19] Sulaiman, Umar. 2017. Pengaruh penggunaan Media Big Book dalam Pembelajaran terhadap Keterampilan Literasi Siswa Kelas Awal Madrasah Ibtidaiyah Negeri BantaBantaeng Makasar. Jurnal Al-Kalam, 9 (2), 193-204.

[20] Chung, Mi-Hyun \& Barbara Keckler, Mercy College. 2016. Shared-Book Experience Using Science-Themed Books to Develop Scientific Literacy: An Interactive Approach with Struggling Readers. The Language and Literacy Spectrum Vol 26. https://files.eric.ed.gov/fulltext/EJ1108465

[21] Aulia Rahmani, F., Eni R, dan Eusabinus B. (2018). The Use Of Big Book To Increase Students English Early Reading Skills. Jurnal Pendidikan dan Pembelajaran

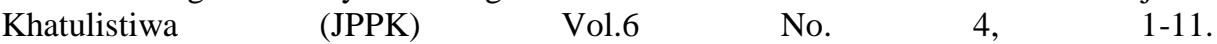
https://jurnal.untan.ac.id/index.php/jpdpb/issue/view/735

[22] Azimi, Ani Rusilowati, dan Sulhadi. (2017). Pengembangan Media Pembelajaran IPA Berbasis Literasi Sains untuk Siswa Sekolah Dasar. Pancasakti Science Education Journal Volume 2 Nomor 2, 145- 145

[23] Putri, N.K. dan Mintohari. (2017). Pengaruh Media Big Book Terhadap Hasil Belajar Siswa Tema Ekosistem di Sekolah Dasar. JPGSD Volume 03 Nomor 02, 1178-1187

[24] Krisna Anggraeni. (2016). Efektivitas Metode Steinberg dengan Media Big Book Terhadap Keterampilan Membaca Nyaring Jurnal Cakrawala Pendas, Vol. 2, No. 1, 8394

[25] Purwanti, K.Y. dan Elina I. A. (2019). Efektivitas Penggunaan Media Big Book Literasi Terhadap Keterampilan Membaca Permulaan Siswa Kelas 1 Sekolah Dasar. JGK: Jurnal Guru Kita. Vol. 3 No. 4, 349 - 354

[26] Ramadhan, N. \& Khairunnisa, K. (2021). Efektivitas penggunaan media pembelajaran big book subtema indahnya keberagaman budaya negeriku. Tarbiyah wa Ta'lim: Jurnal Penelitian Pendidikan dan Pembelajaran, 8(1) 49-60. doi: https://doi.org/10.21093/twt.v8i1.3208

[27] Sigit Vebrianto Susilo, Devi Afriyuni Yonanda dan Rieta Pratiwi. (2020). Jurnal Tunas Bangsa

[28] Yayu Mega Purnamasari dan Wuri Wuryandani. (2020). Media Pembelajaran Big Book Berbasis Cerita Rakyat untuk Meningkatkan Karakter Toleransi pada Anak Usia Dini. Jurnal Obsesi : Jurnal Pendidikan Anak Usia Dini. Volume 4 Issue 1, 90-99

[29] Karyadi, Agung Cahya. (2018). Peningkatan Keterampilan Berbicara Melalui Metode Storytelling Menggunakan Media Big Book. Jurnal Pengabdian Masyarakat Ilmu Keguruan dan Pendidkan, Vol. 1 No. 02, 81-90

[30] Pramujiono, A., Dudu S.S., dan Reza R. (2020). Model Pembelajaran Multiliterasi Berbantuan Media Big Book Terhadap Kemampuan Membaca Pemahaman Siswa di Kelas V Sekolah Dasar. JPD: Jurnal Pendidikan Dasar, 282-290. DOI: doi.org/10.21009/JPD.011.28 
[31] [31] Sartika, \& Octafiani, M. (2019). Pemanfaatan Kahoot Untuk Pembelajaran Matematika Siswa Kelas X Pada Materi Sistem Persamaan Linear Dua Variabel. Journal On Education, 01(03), 373-385

[32] Setiyaningsih, Gunanti dan Amir Syamsudin. (2019). Pengembangan Media Big Book Untuk Meningkatkan Kemampuan Literasi Anak Usia 5-6 TahunScholaria: Jurnal Pendidikan dan Kebudayaan, Vol. 9 No. 1, 19-282. https://doi.org/10.24246/j.js.2019.v9.i1 